\title{
Employee Performance Measurement Development Based on Green HRM Indicators
}

\section{Nury Ariani Wulansari, Rini Setyo Witiastuti, and Siti Ridloah}

Department of Management, Faculty of Economic, Universitas Negeri Semarang, Semarang, Indonesia

\section{Abstract}

The purpose of this study is to develop employee performance indicators based on Green HRM, quantitatively test the influence of Green HRM implementation on employee performance and answer black box that explain how the implementation of Green HRM can improve employee performance through the effect of mediation role (Organizational Identification) and moderation (Perceived Organizational Support). The sample of this research is 90 respondents from six state universities in Central Java

Corresponding Author: Nury Ariani Wulansari nuryariani@mail.unnes.ac.id

Received: 7 August 2018 Accepted: 15 September 2018 Published: 22 October 2018

Publishing services provided by Knowledge $\mathrm{E}$

(c) Nury Ariani Wulansari et al. This article is distributed under the terms of the commons Attribution License, which permits unrestricted use and redistribution provided that the original author and source are credited.

Selection and Peer-review under the responsibility of the ICE-BEES 2018 Conference Committee.
Province with simple random sampling technique. Implementation of Green HRM is not only needed in the business world only, but also in education that has committed to implement environmental management system in its business process. The result of this study indicates that employee performance indicators based on Green HRM are formed from policies that support green behavior and green health in the office and also waste management policies. This research also supports the result that the implementation of Green HRM can increase the sense of ownership of employees in the organization that ultimately can improve its performance. However, the role of moderation was not significantly supported. This means that organizational support for successful implementation of Green HRM is not very necessary as long as employees understand the organization's identity well. Suggestions for this study are, although the organizational support is not proven to moderate the successful implementation of Green HRM on the high organizational identification perceived by employees, but organizational support is still needed to support employee performance.

Keywords: Green HRM, Organizational Identification, Job Performance, Perceived Organizational Support

\section{Introduction}

Green company concept has become a demand in the globalization era. At the business level, each company competes for creating the organizational performance indicators and employee performance that is adjusted to the vision, missions, goals and trend 
development of environmentally-friendly demand. Paradigm change from economicbased costing to green economic-based costing has made organization experiencing many adjustments by creating performance measurement (employee behavior) oriented to formation of pro-environment employees (Pendey et al., 2013). For all this time being, research has developed various indicators of employee performance, such as creative performance, innovative performance, adaptive performance and so forth. This notion is supported by the preceding research carried by Obaid and Alis (2015), Arulrajah et al. (2015) and Renwick et al. (2013), suggesting that Green HRM is one of factor that is able to influence the performance of an organization. Nonetheless, the employee performance measurement viewed from employee management policy, to support the implementation of environmental management system, has not been developed. Poor business activities that ignore the concept of green environment organization gives impact on long-term company adversity. Therefore, company starts to implement the environmental management system for its sustainable existence. In fact, this implementation has not gone as expected, some researchers then proceed to further examine the causes of detrimental factors in implementing the environmentally management system, starting from planning aspect, organizing aspect, until controlling aspect $[13,22]$.

One of the most significant reasons for the implementation failure is that there is no support for employee management policies that employ green elements or so called Green HRM, thereby it does not create green behavior (employee behavior that is aware of environment). Dutton et al. (1994) and Smidts et al. (2001) argued that Green HRM encourage and provide opportunities for the employee to participate and involve in green activities.

The implementation of Green HRM is proven to affect the organization in achieving its competitive advantage $[7,9,11]$. Green HRM is a new concept related to the employee management involving HRM practices with eco-friendly principle. The implementation of Green HRM is not only required in the business world, but also in the education world, especially at university as a source of knowledge to shape green behavior of its members $[4,5,22]$. This study is considered pivotal for some reasons. First, it fulfills the demands of employee performance indicators development of Green HRM-based, in which has not been broadly implemented. Second, it analyzes whether HR practices have been well-implemented (recruitment, selection, placement and management of employees) by taking into account the eco-friendly aspects. Third, it analyzes the process of pro-environmental moral formation for employees, whose its organization have committed to implement an environmental management system. 


\section{Green Human Resource Management (HRM)}

Human Resource Management is defined as a system of activities, functions, and process referring to the development and upkeep of human resource in an organization [5]. To implement an effective green human resource management, improving technical and management skill related to green concept for all members of company is necessary required. Thus, the company will seek for innovation and appropriate management technique which gives significant and sustainable impact for the company in order to gain a competitive advantage [5].

To evolve the company framework that fits the green management targets, it is also needed an effective HRM system starting from employee recruitment, compensation system, rewards and evaluation processes that include points on environmental conservation awareness, as well as environmentally sound training and development programs. According to Cherian and Jacob (2012) the greater the influence of green HRM policies, the greater the ability of company adaptation to implement environmental management systems that have been established.

The importance of implementing a good green HRM is very influential in developing employee morale which will help to achieve the benefits for both employees and the company. Employees who are active in environmental management activities will have well contribution to the implementation of the company's green environmental strategy so as to create greater opportunities for the emergence of improvisation and innovation related to be more conservation and organization activities. This will create green products and benefits of cost savings in organizational activities, even it will increase stakeholder satisfaction in certain situations and conditions. Currently, the stakeholder paradigm has been leaning towards companies that implement good environmental standards so that the application of green human resources policy can be as a strategy to gain competitive advantage in today's business world [5].

\section{Organizational Identifications}

Tajfel (1972) defined social identity as individual knowledge that belongs to a particular social group, along with some emotional meaning and value to its group membership. Social identity is the knowledge of being a member of a group and what values determining membership in a group, social identity also involves emotional attachment to the group. Tajfel and Turner (1979) argued that social identity rests on the fundamental 
difference between social identity, which is related to group membership, and personal identity relating to personal relationships.

Organizational identification relates to the perception of organizational members to have "unity" values with an organization [3]. Based on social identity theory, organizational identification has a positive effect on employee behavior to realize organization goals and objectives. It is therefore important for leaders to develop employee organization identification (Hekman, et al., 2009).

Organizational identification is essentially determined by cognitive and emotional components. The cognitive component shows an individual's interests or feelings he agrees with the organization, as well as the perception he can receive calculative benefits if he follows the organization [3]. It also shows the extent to which a person identifies himself as a member of the organization, while the emotional component reflects the pride of the individual being a member of an organization. The emotional component of organizational identification plays an important role in creating a positive image of the organization, and helps to develop identification with the organization (Tajfel, 1972). Individuals have two primary and basic motives for identification of an organization. The first motive is a self-need, which helps an individual to find a unique place and feel different from other members of the organization or society. The second motive is evolved from the need for self-improvement and self-esteem, which means that an individual aspires to be honored and proud through association membership in an organization Pratt (1998).

\section{Perceived Organizational Support}

Employees' behavior in the organization is not only influenced by job satisfaction, but also by other factors, that are, Perceived Organizational Support towards himself. Eisenbergeret et al. (1986) defined Perceived Organizational Support as the global employees' beliefs concerning the extent to which the organization values their contribution and cares about their well-being. Global beliefs here means that there is an employees' consistency regarding various assessments of the organization that may be provided to them and the actions of organization that can be both profitable and disadvantageous. Perceived organizational support is the main concept of organizational support theory $[10,18,19]$.

Organizational support theory claims that to meet socio-emotional needs and to evaluate the benefits of the effort improvement, employees form a general perception of how far organizations value their contribution and care for their well-being 
(perceived organizational support). Employees' concern on organization and achievement of organizational goals can be shown by exhibiting a positive attitude and work behavior as expected by the organization.

\section{Employee Performance (Based on Green Performance)}

Basically, an employee when carrying out the tasks assigned to him is expected to show the best performance, more than that, that performance is influenced by various factors that are important for the improvement of the work as the goal of the organization or institution where employees work.

Performance needs to be measured by the leaders in order to know the extent to which the performance improvement of an employee in particular and the organization in general. Definition of the employee performance proposed by Mangkunegara (2004: 67), stated that: Performance is the work of quality and quantity achieved by an employee in performing their duties regarding to the responsibilities given.

The definition of employee performance presented by Prawirosentono in his book entitled Human Resource Management Employee Performance Policy (1999), which noted: Performance is the work result that can be achieved by a person or group of people within an organization, in accordance with the authority and responsibility of each in the framework of efforts to achieve the objectives of the organization legally, not violating the law and based on the moral and ethical values. Another opinion about the definition of performance provided by Rivai (2005) is as follows: Employee performance is the willingness of a person or group of people to do an activity and refine it in accordance with its responsibilities and the expected results.

From those aforementioned notions, it can be deduced that performance is the result of work that can be achieved both by a person or a group in an organization in accordance with each of responsibilities in order to reach the goals of organization.

Performance is a term generally used for some or all actions of an organization in a period with reference to a number of standards such as past or projected costs on the basis of efficiency, accountability of a management. Performance itself refers to the level of achievement of tasks that make up an employee's job. Performance reflects how employees meet the requirements of a job. However, it is often misinterpreted as an attempt to reflect the energy released, in which performance is measured in terms of results. In this study, employee performance will be defined more specific - seen from their "green" performance. Green performance basically takes the definition of performance in general, in which it was developed with the aim of adjusting Green 
HRM as its management strategy. Green Performance is proposed by Opatha and Arulrajah (2014), that is, seeing the concept of performance from a "green" point of view as to the extent to which a worker engages in behavior (actions and activities) and produces performance referring to conservation values over a period of time. This is interesting, considering that Green HRM is closely related to the implementation or practice of Human Resource, which is said to be "environmentally friendly" or "conservation". It is important to see how far Green HRM practices can affect the performance of those "green" employees.

\section{Hypotheses}

Green HRM is a managerial implication that can affect the level of organizational identification of employees. The higher the level of organizational identification of employees, meaning the better matching the value and purpose of employees with the organization. Thus, in the end, employees with high levels of organizational identification will show more positive work performance, such as high performance. It shows that organizational identification can be a variable that mediates the relationship of Green HRM on Employee Performance.

On the other hand, the high or low organizational identification is also strongly influenced by the employees' perceived organizational support. Green HRM, directly, indeed can affect the employee organizational identification. However, some literatures indicate that a positive relationship between Green HRM and Organizational Identification can be strengthened or weakened by other aspects. One aspect that can strengthen the relationship between Green HRM and organizational identification is the perceived organizational support that is well perceived by the employees.

Based on this framework, the hypotheses are proposed as follows:

H1: Green HRM has positive effect on employee performance of Public University employees in Central Java.

H2: Green HRM has positive effect on Organizational Identification of Public University employees in Central Java.

H3: Organizational Identification has positive effect on employee performance in Central Java.

$\mathrm{H}_{4}$ : Organizational Identification mediates the relationship between Green HRM and the performance of Public University employees in Central Java. 
$\mathrm{H}_{5}$ : the relationship between Green HRM on Organizational Identification is moderated by Perceived Organizational Support.

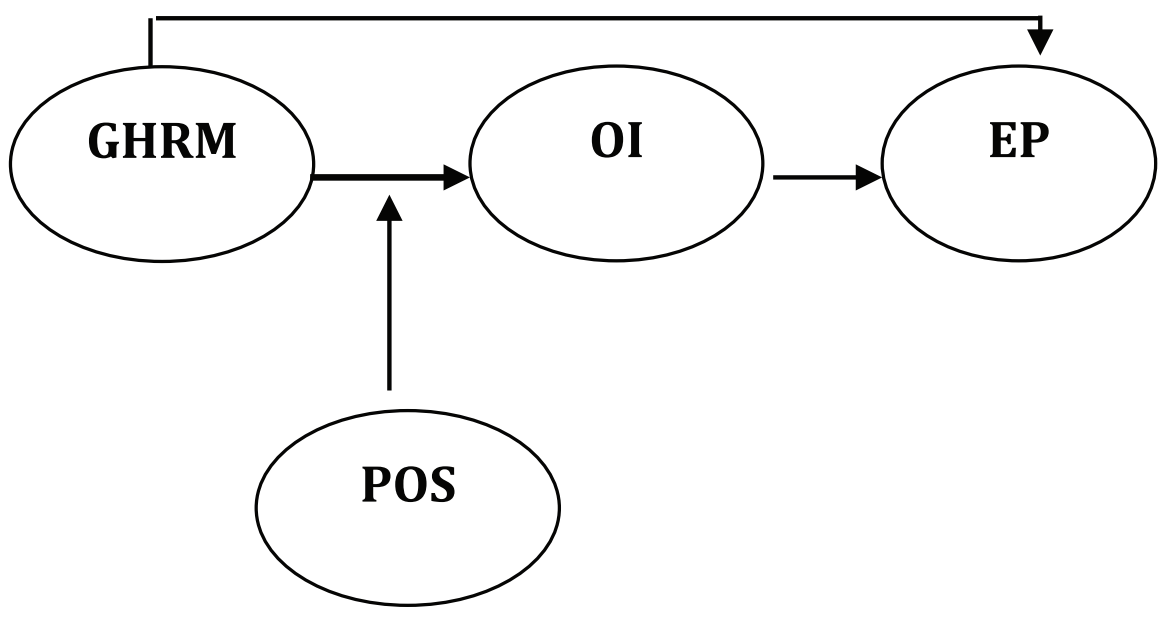

Figure 1: Research Model.

\section{Research Method}

\subsection{Research design and population}

Quantitative approach was used as the design of this study. Sources of data on quantitative study were derived from primary data sources. This study aims to examine the effect of Green HRM, Organizational Identifications, on Employee Performance which is moderated by Perceived Organizational Support. The population of this study is university employees in Central Java, consisting of six public universities, that is, Diponegoro University, Sebelas Maret University, Semarang State University, Jendral Soedirman University, Tidar Magelang University, Walisongo State Islamic University. Speaking of sampling technique used in this study, purposive sampling is chosen, in which the sample determined is based on certain consideration. As for sampling consideration, the respondents (employees) are them who have 5 years working experience. This consideration is referring to the fact that 5 years-experience employees have been able to identify their organization clearly. There are 90 respondents as the sample in this study.

The analysis of structural equation modeling (SEM) with warp PLS program was used to test the hypotheses. This statistical analysis tool was chosen because it has some advantages. First, SEM-PLS is suitable for the research model using latent variables (variables that cannot be directly measured) and calculating the measurement error. Second, SEM analysis enables to test multiple dependence simultaneously as in 
this research model. Third, component-based SEM (PLS) is able to estimate relatively complex model with small-size sample.

\section{Result and Discussion}

\subsection{Instrument test (validity test and reliability test)}

Convergent validity and discriminant validity are used in this study. Hereafter is the explanation of convergent validity and discriminant validity.

Convergent validity is measured by using factor loading for the reflective indicator model or component loading for formative indicator mode. If the loading factor $\geq 0,30$ or the loading factor and component loading is significant, then the those indicators meets convergent validity.

Based on the calculation using WarpPLS 6.0, the result of convergent validity test on the statement items of variables shows that all of the statements are claimed as convergent validity because the loading factor $\geq 0.30$. Thus, those statement items are used in this study. Besides the convergent validity test, there is discriminant validity test by examining each variable. After having the result of convergent validity, the next step is to get the discriminant validity test of the questionnaires, which is seen from AVE (Average Variance Extracted) root value with correlation coefficient of the relevant variables and other variables.

The questionnaire discriminant validity can be seen from the comparison of AVE root value and correlation coefficient. If AVE root value is greater than correlation coefficient with other variables, the questionnaire is discriminant valid

It is demonstrated in Table 3:

TABLE 1: AVE Root and Correlation Coefficient.

\begin{tabular}{l|c|c|c|c|} 
& GHRM & OI & EP & POS \\
\hline GHRM & $\mathbf{0 . 6 4 9}$ & 0.546 & 0.510 & 0.522 \\
\hline OI & 0.546 & $\mathbf{0 . 8 0 8}$ & 0.571 & 0.431 \\
\hline EP & 0.510 & 0.571 & $\mathbf{0 . 7 4 8}$ & 0.335 \\
\hline POS & 0.522 & 0.431 & 0.335 & $\mathbf{0 . 8 3 0}$ \\
\hline \multicolumn{2}{l|l}{ Source: Processed Primary Data (2018) } \\
\end{tabular}

Based on Table 3, the result of AVE root test and Correlation Coefficient show that all statement items are greater than the correlation of the relevant variables. Thus, discriminant validity is fulfilled, meaning that all statements are able to represent the problems in this study and fit with the actual condition in the object of the study. 


\subsection{The result of reliability test}

The test result of instrument reliability is mentioned in the following table:

TABLE 2: Composite Reliability and Cronbach's Alpha.

\begin{tabular}{l|c|c|c|} 
No. & Variable & $\begin{array}{c}\text { Composite } \\
\text { Reliability } \\
\text { Coefficient }\end{array}$ & $\begin{array}{c}\text { Cronbach's } \\
\text { Alpha } \\
\text { Coefficient }\end{array}$ \\
\hline 1 & GHRM & 0.886 & 0.858 \\
\hline 2 & OI & 0.919 & 0.893 \\
\hline 3 & KK & 0.946 & 0.937 \\
\hline 4 & POS & 0.952 & 0.934 \\
\hline
\end{tabular}

Based on Table 4 about the result of reliability test on the variables in this study describes that all variables have met composite reliability because composite reliability coefficients $>0.70$ and all variables also have met internal consistency reliability because the cronbach's alpha coefficients $>0.60$, so all variables have met composite reliability and internal consistency. It means that all those statements are able to measure the problem constantly, thus it can be deduced as the reliable measuring tool.

\subsection{Fit model and quality indices}

The criteria mentioned in the goodness of fit model in the table 5 is the rule of thumb, so the results of the test should not be applied rigidly and absolutely. When there are one or two indicators of fit model and quality indices, the model still can be used. Following table 5 is the result of the test.

It can be seen from Table 5 that the goodness of fit model has a good result to explain the relationship between latent variables and their assumption.

\subsection{The result of direct hypotheses testing}

The hypotheses testing uses resampling method and t-test is. The principle of hypotheses testing is completed as follows, if $p$-value $\leq 0.10$ (alpha $10 \%$ ), it is said significantly weak If $p$-value $\leq 0.05$ (alpha $5 \%$ ), it is said significant. And if $p$-value $\leq$ 0.01 (alpha 1\%), it is said significantly high, as described in table 6. 
TABLE 3: Fit Model and Quality Indices.

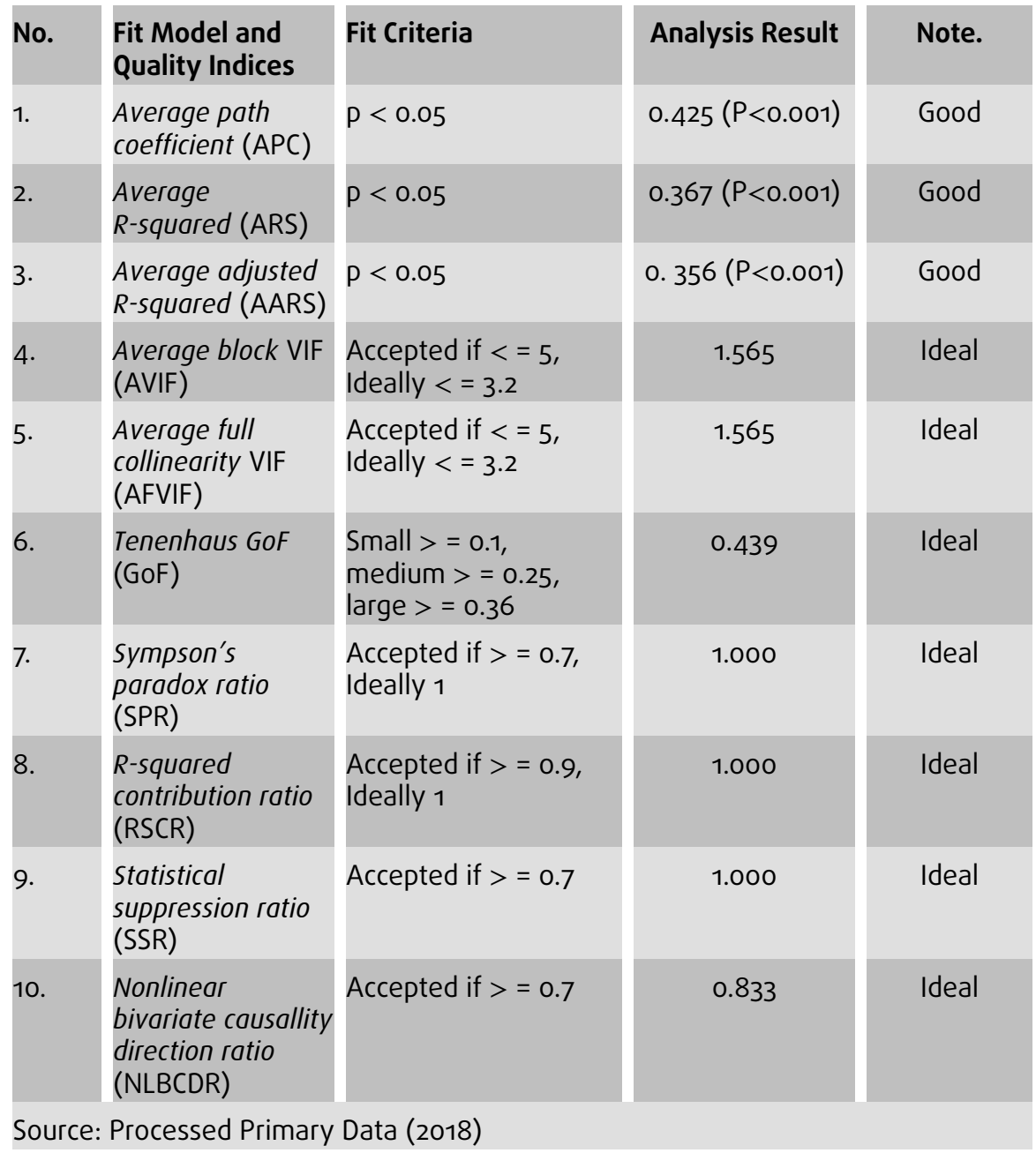

TABLE 4: The Result of Direct Effect Hypotheses Testing.

\begin{tabular}{|c|c|c|c|c|c|}
\hline No. & $\begin{array}{r}\text { Th } \\
\text { Relatio } \\
\text { amo } \\
\text { Varia }\end{array}$ & $\begin{array}{l}\text { ship } \\
\text { ges } \\
\text { les }\end{array}$ & $\begin{array}{c}\text { Path } \\
\text { Coefficient }\end{array}$ & P-Value & Note \\
\hline 1. & GHRM & OI & $0.530 * \star$ & $<0.001$ & Significantly high \\
\hline 2. & GHRM & EP & $0.233^{\star \star}$ & 0.010 & Significantly high \\
\hline 3. & OI & EP & $0.651^{* *}$ & $<0.001$ & Significantly high \\
\hline
\end{tabular}




\subsection{The result of moderating and mediating hypotheses testing}

TABLE 5: The Result of Moderating and Mediating Hypotheses Testing.

The relationship
between variables
GHRM OI

\begin{tabular}{c}
$\begin{array}{c}\text { Path } \\
\text { Coefficient }\end{array}$ \\
0.345 \\
\hline 0.094 \\
\hline
\end{tabular}

P-Value

Note

Source: Processed Primary Data (2018)

\subsection{Effect of Green HRM (GHRM) on organizational identification (OI)}

Based on table 6, the result of direct effect hypotheses testing, shows that the effect of Green HRM (GHRM) on Organizational Identification (OI) with the path coefficient is 0.530 and $p<0.001$. Considering that $p<0.01$, it is said to be significantly high, that is, $\mathrm{H}_{1}$ is supported. The path coefficient is positive (0.530) indicating that the higher the effect of Green HRM (GHRM), the higher Organizational Identification will be.

Likewise, Shen et al. (2016) and Jiang and Bear (2012) suggested that Green HRM development will improve employee performance if there is psychological mechanism and social transaction. According to the aforementioned statement, the situation which the employees identify their conformity or congeniality between the values possessed and the organization values will be more improved by Green HRM increase.

\subsection{Effect of Green HRM (GHRM) on employee performance (EP)}

Based on table 6, the result of direct effect hypotheses testing presents that the effect of Green HRM (GHRM) on Employee Performance (EP) with the path coefficient is 0.233 and $p=0.010$. Considering that $p \leq 0.01$, it is said significantly high, that is, $\mathrm{H}_{2}$ is supported. The path coefficient is positive (0.233) which indicates that the higher the effect of Green HRM (GHRM), the higher the Employee Performance (EP). It is in line with the study conducted by Obaid and Alis (2015), Arulrajah et al. (2015) and Renwick et al. (2013), concluding that Green HRM is a factor that can influence an organization performance. It can be inferred that the performance shown by employees will be improved by the improvement of Green HRM. The organization implementing Green HRM will affect the employee morale formation that environmentally aware. 


\subsection{Effect of organizational identification (OI) on employee performance (EP)}

Table 6 about the the result of direct effect hypotheses testing implies that the effect of Organizational Identification (OI) on Employee Performance (EP) with the path coefficient is 0.651 and $p<0.001$. Considering that $p<0.01$, it is said that significantly high, so $\mathrm{H}_{3}$ is supported. The path coefficient is positive (0.651) indicating that the higher the Organizational Identification (OI) effect, the higher Employee Performance (EP) will be. This view is supported by Shen et al. (2016), arguing that Green HRM development will improve employee performance if there is psychological mechanism and social transaction. According to those facts, the situation which employees identify their conformity and congeniality between the values possessed and the organization values will increase employee performance.

\subsection{Mediating effect of organizational identification between Green HRM (GHRM) on employee performance (EP)}

Based on table 7, the result of mediation hypotheses testing, indicates that the mediating effect of Organizational Identification between Green HRM (GHRM) on Employee Performance (EP) with path coefficient is 0.345 and $p<0.001$. Considering that $p<$ 0.01 , it is said significantly high, that is, $\mathrm{H}_{4}$ is supported. It means that Organizational Identification (OI) is the mediating variable because it connects between Green HRM (GHRM) on Employee Performance (EP). In the same vein, Shen et al. (2016) and jiang and Bear (2012) pointed out that Green HRM development will improve employee performance if there is a psychological mechanism and social transaction. Regarding to this fact, Green HRM enables to encourage the situation in which the employees are able to identify the conformity and congeniality between the values possessed and the organization values. Then, those organizational identification improvement will improve employee performance.

\subsection{Moderating effect of perceived organizational support between Green HRM (GHRM) on organizational identification (OI)}

Table 7 presenting the result of moderation hypotheses testing shows that moderating influence of Perceived Organizational Support (POS) of Green HRM (GHRM) on 
Organizational Identification (OI) with path coefficient is 0.094 and $p<0.180$. Considering that $\mathrm{p}<0.01$, it is said not significant, meaning that $\mathrm{H}_{5}$ is not supported. Thus, Perceived Organization Support cannot moderate the relationship of Green HRM (GHRM) on Organizational Identification (OI). It is contrary to the notion suggesting that the assessment of green employee performance cannot be carried out if organization support give is too weak. It means that the control and commitment of organization should be applied in a non-impartial policy to support the implementation of Green $\operatorname{HRM}[9,11]$.

It has been suggested that the high or low of perceived organizational support has not been able to strengthen positive effect of Green HRM on organizational identification. It seems possible that the results are due to respondents' perception on Green HRM is higher $(40,22)$ compared to perceived organizational support $(32,30)$. Thus, moderating effect (strengthen) from POS is not significantly play role. Other reason is that perceived organizational support is likely to be more suitable as exogenous variable for organizational identification variable $[6,7]$

\section{Conclusion and Recommendation}

Taken together, the current data highlight that there is an effect of green HRM on organizational identification which indicating that the higher green HRM effect, the higher organizational identification. Green HRM also affects employee performance, meaning that the higher green HRM effect, the higher employee performance will be. Organizational identification on employee performance is also proven to have significant impact, the higher organizational identification, the higher employee performance will improve.

Referring to the result, it indicates that there is a mediating role of organizational identification between green HRM on employee performance. It means that organizational identification is mediating variable since it is likely that a connection is exist between green HRM and employee performance. Thereby, green HRM enables to enhance certain situation in which the employees identifying conformity or congeniality between the pre-exist values possessed and the organization values. Those organizational identification improvements will improve employee performance as well. Explained in this study, the high or low of perceived organizational support is not able to strengthen the positive effect of green HRM in organizational identification. Some causes are, that is, respondents' perception on green HRM is higher compared 
to perceived organizational support, leading to moderating effect (strengthen) from POS is not significant.

This research extends our knowledge of Green HRM as an important tool to implement, not only in profit organizations, but also in education institution (universities). Organization in general and Universities in particular need to implement and improve the awareness of Green HRM practices in order to get positive work outcome.

This study is limited by the small number of samples size. It would be interesting to add more samples for the further research. Moreover, this study only uses a quantitative approach, in such a way that it has not been able to provide answers related to considerably deeper study. It is suggested to use mix method approach to obtain in-depth phenomena illustration.

\section{References}

[1] Arulrajah, A. A., Opatha, H. H. D. N. P., \& Nawaratne, N. N. J. (2015). Green human resource management practices: A review. Sri Lankan Journal of Human Resource Management, 5(1).

[2] Ashforth, B. E., Harrison, S. H., \& Corley, K. G. (2008). Identification in organizations: An examination of four fundamental questions. Journal of management, 34(3), 325374 .

[3] Ashforth, B. E., \& Mael, F. (1989). Social identity theory and the organization. Academy of Management Review, 14(1), 20-39.

[4] Baried, A. B., Septarini, N., \& Rahman, W. I. (2012). Analisis Pengaruh Kebijakan Campus Social Responsibility terhadap Kesejahteraan Masyarakat Sekitar (Studi Kasus Tiga Perguruan Tinggi Negeri di Surabaya). Prosiding Seminar dan Konferensi Nasional Manajemen Bisnis.

[5] Cherian, J. P., \& Jacob, J. (2012). A study of green HR practices and its effective implementation in the organization: A review. International Journal of Business and Management, 7(21), 25.

[6] Dai, K., \& Qin, X. (2016). Perceived Organizational Support and Employee Engagement: Based on the Research of Organizational Identification and Organizational Justice. Open Journal of Social Sciences, 4(12), 46-57.

[7] Demir, K. (2015). The Effect of Organizational Justice and Perceived Organizational Support on Organizational Citizenship Behaviors: The Mediating Role of Organizational Identification. Eurasian Journal of Educational Research, 60, 131-148. 
[8] Dutton, J. E., Dukerich, J. M., \& Harquail, C. V. (1994). Organizational images and member identification. Administrative Science Quarterly, 39, 239-263.

[9] Erdem, H., Gökmen, Y., \& Türen, U. (2015). Mediating Role of Perceived Organizational Support on the Impact of Psychological Capital on Organizational Identification. işletme Araștırmaları Dergisi, 7(2), 38-62.

[10] Eisenberger, R., Huntington, R., Hutchison, S., \& Sowa, D. (1986). Perceived Organizational Support.journal of Applied Psychology, 82(5), 812-820

[11] He, H., \& Brown, A. (2012). Organizational Identity and Organizational Identfications: A review of The Literature and Suggestions for Future Research. Tesis. University of Warwick.

[12] He, H., Wang, W., Zhu, W., \& Harris, L. (2015). Service workers' job performance: The roles of personality traits, organizational identification, and customer orientation. European Journal of Marketing, 49(11/12), 1751-1776.

[13] Jiang, K., Lepak, D. P., Hu, J., \& Baer, J. C. (2012). How does human resource management influence organizational outcomes? A meta-analytic investigation of mediating mechanisms. Academy of Management Journal, 55, 1264-1294.

[14] Obaid, T. F., \& Alias, R. B. (2015). The impact of green recruitment, green training and green learning on the firm performance: conceptual paper. International Journal of Applied Research, 1(12), 951-953.

[15] Opatha, H. H. D. N. P., \& Arulrajah, A. A. (2014). Green human resource management: Simplified general reflections. International Business Research, 7(8), 101-112.

[16] Purwanto, B. (2010). Manajemen Sumber Daya Manusia Berbasis Proses: Pola Pikir Baru Mengelola Sumber Daya Manusia. Jakarta: Grassindo

[17] Renwick, D. W., Redman, T., \& Maguire, S. (2013). Green human resource management: A review and research agenda. International Journal of Management Reviews, 15, 1-14.

[18] Rhoades, L., \& Eisenberger, R. (2002). Perceived Organizational Support: A review of the literature. Journal of Applied Psychology, 87, 698-714.

[19] Shore, L. M., \& Shore, T. H. (1995). Perceived organizational support and organizational justice. Organizational politics, justice, and support: Managing the social climate of the workplace, 149,164 .

[20] Smidts, A., Pruyn, A. T. H., \& Van Riel, C. B. M. (2001). The impact of employee communication and perceived external prestige on organizational identification. Academy of Management Journal, 44, 1051-1062. 
[21] Setiawan, B. (2012). Peran Manajemen Sumber Daya Manusia Stratejik Terhadap Kinerja Perusahaan (Studi Kasus Pada Perusahaan Jasa PT. X di Sidoarjo). Skripsi. Manajemen Unika Widya Mandala Surabaya.

[22] Shen, J., Dumont, J., \& Deng, X. (2016). Employees' perceptions of green HRM and non-green employee work outcomes: The social identity and stakeholder perspectives. Group \& Organization Management, 1-29.

[23] Tajfel, H., \& Turner, J. C. (1979). An integrative theory of intergroup conflict. The social psychology of intergroup relations, 33(47), 74.

[24] Veithzal Rivai (2005). Manajemen Sumber Daya Manusia. Jakarta: Raja Grafindo Persada. 